\title{
Metallocene Sulfide Chemistry of Nioblum and Tantalum: New Insights Into the Formation of Niobium-Polysulfido Complexes and Synthesis, Structure, and Reactivity of $\mathrm{Cp}_{2}^{\prime}{ }_{2} \mathrm{Ta}\left(\eta^{2}-\mathrm{S}_{2}\right) \mathrm{H}\left(\mathrm{Cp}^{\prime}=t-\mathrm{BuC}_{5} \mathrm{H}_{4}\right)$
}

\author{
Hans-Jürgen Bach, Henri Brunner, and Joachim Wachter* \\ Institut für Anorganische Chemie der Universität Regensburg, D-8400 Regensburg, Germany
Marek M. Kubicki, Jean-Claude Leblanc, Claude Moise, and Florence Volpato
Laboratoire de Synthèse et d'Electrosynthèse Organométalliques, Université de Bourgogne, F-21100 Dijon, France

\author{
Bernd Nuber and Manfred L. Ziegler ${ }^{\dagger}$ \\ Institut für Anorganische Chemie der Universität, D-6900 Heldelberg, Germany \\ Received October 30, 1991
}

Summary: The previously described reaction of $\mathrm{Cp}_{2}^{\prime}{ }_{2} \mathrm{NbH}_{3}$ $\left(\mathrm{Cp}^{\prime}=t-\mathrm{BuC}_{5} \mathrm{H}_{4}\right)$ with $\mathrm{S}_{8}$ was investigated with regard to the kinetic stablization of as yet elusive intermediates during the formation of the polysulfide complex $\mathrm{Cp}^{\prime}{ }_{4} \mathrm{Nb}_{2} \mathrm{~S}_{9}$ (1). Therefore, the permethylated complex $\mathrm{Cp}_{2}{ }_{2} \mathrm{NbS}_{3} \mathrm{H}$ (2; $\mathrm{Cp}^{*}=\mathrm{C}_{5} \mathrm{Me}_{5}$ ) and the Ta complex $\mathrm{Cp}_{2}^{\prime}{ }_{2} \mathrm{TaS}_{2} \mathrm{H}$ (3) were synthesized in a related reaction and structurally investlgated. Desplte the problematic localization of the hydride atom during $X$-ray crystallographic studies, the molecules can be described in a proper manner: Characteristic of 2 and 3 are $M\left(\eta^{2}-S_{2}\right)$ cores to which elther an SH (2) or a $H(3)$ ligand is attached. Complex 3 is the first known tantalocene sulfide. It readily loses sulfur upon reaction with $\mathrm{PR}_{3}\left(\mathrm{R}=\mathrm{C}_{6} \mathrm{H}_{5}, \mathrm{OCH}_{3}\right)$ and $\mathrm{CH}_{3} \mathrm{I}$ to form compounds 4 and 5 , which both contain the $T a=S$ molety. Attempts to prepare "classical" metallocene sulfides by metathesis reaction of $\mathrm{Cp}^{\prime}{ }_{2} \mathrm{NbCl}_{2}$ and $\mathrm{Li}_{2} \mathrm{~S}_{5}$ gave the polynuclear compounds $\mathrm{Cp}_{3}^{\prime}{ }_{3} \mathrm{Nb}_{3} \mathrm{~S}_{10} \mathrm{O}(6)$ and $\mathrm{Cp}_{4}{ }_{4} \mathrm{Nb}_{4} \mathrm{~S}_{13}$ (7).

A new entry into niobium polysulfide chemistry has recently been found in the reaction of $\mathrm{Cp}_{2}^{\prime} \mathrm{NbH}_{3}$ with elemental sulfur. Among very similar products $\mathrm{Cp}_{4}^{\prime} \mathrm{Nb}_{2} \mathrm{~S}_{9}$ could be characterized unequivocally (eq 1). In this

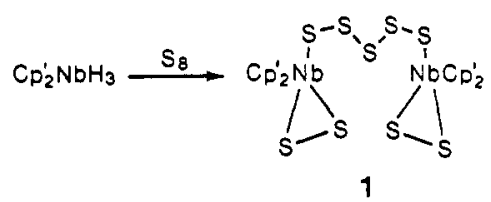

complex two $\mathrm{Cp}_{2}^{\prime} \mathrm{Nb}\left(\eta^{2}-\mathrm{S}_{2}\right)$ units are linked by only one sulfur chain. ${ }^{1}$ The high content of S-S bonds in 1 and related compounds gives rise to a very complex transformation into polynuclear compounds when their solutions are heated. ${ }^{2}$ The question can also be raised of how such compounds, e.g. 1, are formed. This question gets still more important when we consider that during the reaction expressed by eq 1 no intermediates have been observed. From our investigations in cyclopentadienylmetal sulfides we are aware of the influence which is exerted by the substitution degree of the $\mathrm{Cp}$ ligands as well as by the employed metal on the nature of the products. ${ }^{3}$ Indeed, these observations were confirmed when $\mathrm{Cp}^{*}{ }_{2} \mathrm{NbBH}_{4}\left(\mathrm{Cp}^{*}\right.$ $=\mathrm{C}_{5} \mathrm{Me}_{5}$ ), which is more easily accessible than $\mathrm{Cp}_{2}{ }_{2} \mathrm{NbH}_{3}{ }^{4,5}$

${ }^{\dagger}$ Deceased in April 1991.

(1) Brunner, H.; Klement, U.; Wachter, J.; Tsunoda, M.; Leblanc, J.-C.; Moise, C. Inorg. Chem. 1990, 29, 584.

(2) Brunner, H.; Meier, W.; Wachter, J.; Nuber, B.; Ziegler, M. L. J. Organomet. Chem. 1990, 381, C7.

(3) Wachter, J. Angew. Chem., Int. Ed. Engl. 1989, 28, 1613.

0276-7333/92/2311-1403\$03.00/0 was reacted with sulfur (eq 2). ${ }^{1}$

$$
\mathrm{Cp}_{2}{ }_{2} \mathrm{NbBH}_{4}+\mathrm{S}_{8} \rightarrow \mathrm{Cp}_{2}{ }_{2} \mathrm{NbS}_{3} \mathrm{H}
$$

The two isomers $A$ and $B$ have been proposed for the mononuclear complex 2; however, an unambiguous structural attribution has not yet been possible. It is one goal<smiles></smiles>

A

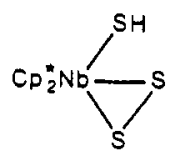

B
2

of this paper to elucidate the definite structure of 2 by means of an X-ray diffraction study.

Another goal is to study the consequence of the "metal effect" on the synthesis of group 5 metallocene chalcogenides by using $\mathrm{Cp}_{2}^{\prime} \mathrm{TaH}_{3}$ instead of $\mathrm{Cp}_{2}^{\prime}{ }_{2} \mathrm{NbH}_{3}$. The structure of the resulting product as well as the first studies of its reactivity will be reported.

A final goal of this investigation was to find out whether $\mathrm{Nb}$ (IV) sulfides are able to play a role in the formation of 1. In this regard it was of interest to test synthetic routes which have been already successfully employed in vanadocene chalcogen chemistry (eq 3), ${ }^{6,7}$ By the method of eq 3 it was attempted to synthesize the $\mathrm{NbS}_{2}$ unit ${ }^{8}$ directly by metathesis from $\mathrm{Cp}_{2}^{\prime}{ }_{2} \mathrm{NbCl}_{2}$ and $\mathrm{Li}_{2} \mathrm{~S}_{2}$ or by thermal decomposition of the eventually formed $\mathrm{Cp}_{2}^{\prime} \mathrm{NbS}_{5}$ to give dinuclear complexes. ${ }^{9}$

$$
\left(\mathrm{RC}_{5} \mathrm{H}_{4}\right)_{2} \mathrm{VCl}_{2}+\left.\underset{\substack{n=2,5 \\ \mathrm{Li}_{2} \mathrm{~S}_{n}}}{\rightarrow} \underset{\left(\mathrm{RC}_{5} \mathrm{H}_{4}\right)_{2} \mathrm{VS}_{n}+2 \mathrm{LiCl}}{n=5}\right|_{\text {heat }}
$$$$
\mathrm{R}=\mathrm{H}, \mathrm{Me}, i-\operatorname{Pr}
$$

(4) Bell, R. A.; Cuhen, S. A.; Doherty, N. M.; Threlkel, R. S.; Bercaw, J. E. Organometallics 1986, 5, 972.

(5) It has already been proved for the $\mathrm{Cp}^{\prime}$ series that the trihydride reacts in the same manner with $\mathrm{S}_{8}$ as the $\mathrm{BH}_{4}$ complex. ${ }^{1}$

(6) Muller, K. G.; Petersen, J. L.; Dahl, L. F. J. Organomet. Chem. 1976, 111, 91. Petersen, J. L.; Dahl, L. F. J. Am. Chem. Soc. 1975, 97 6416.

(7) Köpf, H.; Wirl, A.; Kahl, W. Angew. Chem., Int. Ed. Engl. 1971, 10,137 .

(8) Mononuclear niobocene complexes bearing the $\mathrm{Nb}\left(\eta^{2}-\mathrm{S}_{2}\right)$ moiety are as follows. (a) $\mathrm{Cp}_{2} \mathrm{NbS}_{2} \mathrm{X}\left(\mathrm{Cp}=\mathrm{C}_{5} \mathrm{H}_{5} ; \mathrm{X}=\mathrm{Cl}, \mathrm{Br}, \mathrm{I}, \mathrm{SCN}\right)$ : Treichel, P. M.; Werber, G. P. J. Am. Chem. Soc. 1968, 90, 1753. Roder, R. M. Ph.D. Thesis, University of Wisconsin, 1973; Chem. Abstr. 1974, 81, 30727. (b) $\mathrm{Cp}_{2} \mathrm{NbS}_{2}\left[\mathrm{~S}_{2} \mathrm{P}(\mathrm{OR})_{2}\right]_{2}$ : Viard, B.; Sala-Pala, J.; Amaudrut, J.; Guerchais, J. E.; Sanchez, C.; Livage, J. Inorg. Chim. Acta 1980, 39, 99. (c) $\mathrm{Cp}_{2} \mathrm{NbS}_{2} \mathrm{Me}$ : Amaudrut, J.; Guerchais, J. E.; Sala-Pala, J. J. Organomet. Chem. 1978, 157, C10.

(C) 1992 American Chemical Society 


\section{Experimental Section}

All procedures were carried out under nitrogen with $\mathrm{N}_{2}$-saturated, dry solvents. Elemental analyses were performed by the Mikroanalytisches Laboratorium, Universität Regensburg. IR spectra were obtained with a Beckman 4240 spectrophotometer and a Perkin-Elmer $580 \mathrm{~B}$ instrument. Field desorption mass spectra were run on a Finnigan MAT 311A instrument from toluene solutions. NMR spectra were recorded on Bruker WM 250 and 400 instruments. Complex 2 was prepared as described in ref 1 and recrystallized from toluene.

Preparation of $\mathrm{Cp}_{2}^{\prime} \mathrm{TaS}_{2} \mathrm{H}$ (3). A mixture of $1000 \mathrm{mg}$ (2.35 $\mathrm{mmol})$ of $\left(t-\mathrm{BuC}_{5} \mathrm{H}_{4}\right)_{2} \mathrm{TaH}_{3}{ }^{10}$ and $370 \mathrm{mg}(1.44 \mathrm{mmol})$ of $\mathrm{S}_{8}$ in 60 $\mathrm{mL}$ of toluene was stirred for $4 \mathrm{~h}$ at $25^{\circ} \mathrm{C}$. After chromatographic workup ( $\mathrm{SiO}_{2} /$ toluene) 3 was isolated as a yellow band in $46 \%$ yield. Recrystallization from toluene/pentane gave bright yellow needles. Anal. Calcd for $\mathrm{C}_{18} \mathrm{H}_{27} \mathrm{TaS}_{2}$ : C, 44.26; $\mathrm{H}, 5.57$; mol wt, 488.5. Found: C, 44.23; H, 5.66; mol wt, 487.9 (FD-MS). ${ }^{1} \mathrm{H}$ NMR $\left(\mathrm{C}_{6} \mathrm{D}_{6}\right): \delta 1.23(\mathrm{~s}, 18), 2.79(\mathrm{~s}, 1), 4.09(\mathrm{q}, 2), 4.38(\mathrm{q}, 2), 4.57(\mathrm{q}$ 2), $6.04(\mathrm{q}, 2)$. IR (KBr): $\nu_{\mathrm{S}-\mathrm{s}} 525 \mathrm{~cm}^{-1}$.

Preparation of $\mathrm{Cp}_{2}^{\prime} \mathbf{T a}(\mathbf{S}) \mathbf{H}(4)$. To a solution of $700 \mathrm{mg}$ of $\left(t-\mathrm{BuC}_{5} \mathrm{H}_{4}\right)_{2} \mathrm{TaS}_{2} \mathrm{H}(1.43 \mathrm{mmol})$ in toluene $(60 \mathrm{~mL})$ was added 310 $\mathrm{mg}$ of $\mathrm{P}(\mathrm{OEt})_{3}(1.89 \mathrm{mmol})$. The reaction mixture was refluxed for $4 \mathrm{~h}$, and the solvent was then removed under vacuum. The residual solid was washed with pentane and taken to dryness, giving $425 \mathrm{mg}$ ( $65 \%$ yield) of 4 as a pink solid, which was recrystallized from toluene/pentane. Anal. Calcd for $\mathrm{C}_{18} \mathrm{H}_{27} \mathrm{TaS}$ : $\mathrm{C}, 47.37 ; \mathrm{H}, 5.96 ; \mathrm{mol} \mathrm{wt}, 456.4$. Found: $\mathrm{C}, 46.73 ; \mathrm{H}, 5.71 ; \mathrm{mol}$ wt, 456.6 (FD-MS). ${ }^{1} \mathrm{H}$ NMR $\left(\mathrm{C}_{6} \mathrm{D}_{6}\right): \delta 1.34(\mathrm{~s}, 18), 4.82(\mathrm{q}, 2)$, $5.24(\mathrm{q}, 2), 5.32(\mathrm{q}, 2), 5.67(\mathrm{q}, 2), 7.10(\mathrm{~s}, 1) . \mathrm{IR}(\mathrm{CsI}): \nu_{\mathrm{Tq}-\mathrm{H}} 1859.0$ $\mathrm{cm}^{-1}, \nu_{\mathrm{Ta}=\mathrm{s}} 433.7 \mathrm{~cm}^{-1}$

Preparation of $\mathrm{Cp}_{2}^{\prime} \mathrm{Ta}(\mathrm{S}) \mathrm{I}(5)$. A solution of $270 \mathrm{mg}(0.55$ $\mathrm{mmol})$ of $\left(t-\mathrm{BuC}_{5} \mathrm{H}_{4}\right)_{2} \mathrm{TaS}_{2} \mathrm{H}$ in toluene $(40 \mathrm{~mL})$ was stirred at room temperature for $4 \mathrm{~h}$ with $230 \mathrm{mg}(1.66 \mathrm{mmol})$ of iodomethane. The resulting brown solution was then evaporated, and the residual solid was chromatographed on silica gel. Toluene eluted compound 5 ( $34 \%$ yield) as a greenish band which yielded bright golden leaves after recrystallization from toluene. Anal. Calcd for $\mathrm{C}_{18} \mathrm{H}_{26}$ TaSI: C, 37.12; H, 4.50; mol wt, 582.3. Found: $\mathrm{C}, 37.34 ; \mathrm{H}, 4.22 ; \mathrm{mol}$ wt, 582.2 (FD-MS). ${ }^{1} \mathrm{H}$ NMR $\left(\mathrm{C}_{6} \mathrm{D}_{6}\right): \delta$ 1.34 (s, 18), 4.73 (q, 2), 5.14 (q, 2), 6.08 (q, 2), 6.41 (q, 2). IR (CsI): $\nu_{\mathrm{Ta}-\mathrm{s}} 433.7 \mathrm{~cm}^{-1}$.

Reaction of $\mathrm{Cp}_{2}^{\prime} \mathrm{NbCl}_{2}{ }^{11}$ with $\mathrm{Li}_{2} \mathbf{S}_{5 .}$. To a suspension of 1019 mg (2.47 mmol) of $\mathrm{Cp}_{2}^{\prime} \mathrm{NbCl}_{2}$ in $80 \mathrm{~mL}$ of toluene was added 5 $\mathrm{mL}$ of $0.5 \mathrm{M} \mathrm{Li}_{2} \mathrm{~S}_{5}$ in THF. The mixture was refluxed for $20 \mathrm{~h}$ and then concentrated to $10 \mathrm{~mL}$. Chromatography on silanized $\mathrm{SiO}_{2}$ (column $22 \times 3.5 \mathrm{~cm}$ ) gave a wine red band eluted with toluene, followed by a brown band eluted with THF. The latter consisted of a complex mixture which could not be separated into distinct components. The toluene band was first rechromatographed on $\mathrm{SiO}_{2}$ (eluent toluene) and then on three connected Merck-Lobar columns (type B (310/25 mm); Lichroprep Si60 $(40-63 \mu \mathrm{m}))$ in $4 / 1$ petroleum ether $\left(40-60^{\circ} \mathrm{C}\right) /$ ether to give 6 and then 7. Both orange compounds were recrystallized from $\mathrm{CH}_{2} \mathrm{Cl}_{2}$. Analytical and spectroscopic data for 6 (yield 5.5\%) were consistent with those for the completely characterized $\mathrm{Cp}_{3}{ }_{3} \mathrm{Nb}_{3} \mathrm{~S}_{10} \mathrm{O}^{2}$ Anal. Calcd for $\mathrm{C}_{36} \mathrm{H}_{52} \mathrm{Nb}_{4} \mathrm{~S}_{13}$ (7): C, $34.00 ; \mathrm{H}$, 4.12; S, 32.76; mol wt, 1273.2. Found: C, 33.96; H, 4.05; S, 32.70 mol wt, 1272.2 (FD-MS). ${ }^{1} \mathrm{H}$ NMR $\left(\mathrm{CDCl}_{3}\right): \delta 1.22(\mathrm{~s}, 9), 1.29$ $(\mathrm{s}, 18), 1.34(\mathrm{~s}, 9), 5.26(\mathrm{~m}, 2), 5.35(\mathrm{~m}, 2), 5.42(\mathrm{~m}, 4), 5.72(\mathrm{~m}$ 2), $5.85(\mathrm{~m}, 2), 6.07(\mathrm{~m}, 2), 6.20(\mathrm{~m}, 2)$. IR $(\mathrm{KBr}): \nu_{\mathrm{S}-\mathrm{s}} 544 \mathrm{w}$ $538 \mathrm{w}, 522 \mathrm{~s} \mathrm{~cm}^{-1}$.

\section{Crystallographic Studies}

$\mathrm{Cp}_{2}{ }_{2} \mathrm{NbS}_{3} \mathrm{H}$. A red crystal, obtained from toluene, having the approximate dimensions $0.4 \times 0.46 \times 0.69 \mathrm{~mm}$ was mounted on a Syntex R3 diffractometer. The unit cell was determined and refined from 24 reflections $\left(15<2 \theta<31^{\circ}\right)$. Relevant crystal and data collection parameters are given in Table $\mathrm{I}$. The structure

(9) Bolinger, C. M.; Rauchfuss, T. B.; Rheingold, A. L. Organometallics 1982, 1,1551 .

(10) Green, M. L. H.; Jousseaume, B. J. Organomet. Chem. 1980, 193 , 339.

(11) Tebbe, F. N.; Parshall, G. W. J. Am. Chem. Soc. 1971, 93, 3793. Labinger, J. A. Adv. Chem. Ser. 1978, No. 167, 149.
Table I. Crystal Data and Data Collection Parameters for $\left(\mathrm{C}_{6} \mathrm{Me}_{5}\right)_{2} \mathrm{Nb}\left(\mathrm{S}_{2}\right) \mathrm{SH}(2)$ and $\left(t-\mathrm{BuC}_{5} \mathrm{H}_{4}\right)_{2} \mathrm{Ta}\left(\mathrm{S}_{2}\right) \mathrm{H}(3)$

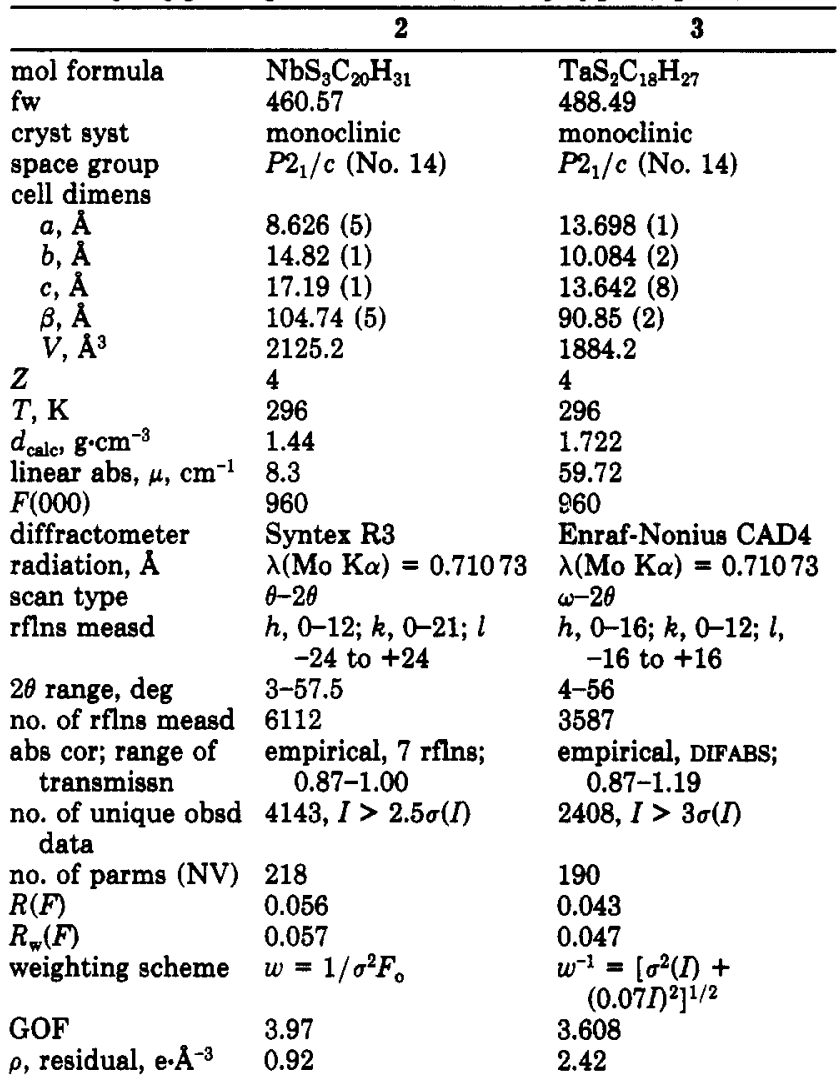

Table II. Atomic Coordinates and Equivalent Isotropic Displacement Parameters $\left(\mathrm{A}^{2}\right)$ for $\mathrm{Cp}_{2}{ }_{2} \mathrm{NbS}_{3} \mathrm{H}(2)$

\begin{tabular}{lcrrr}
\hline atom & \multicolumn{1}{c}{$x$} & \multicolumn{1}{c}{$y$} & \multicolumn{1}{c}{$z$} & \multicolumn{1}{c}{$U_{\text {eq }}{ }^{a}$} \\
\hline $\mathrm{Nb}$ & $0.2581(1)$ & $0.1954(1)$ & $0.1649(1)$ & $41(1)$ \\
$\mathrm{S} 1$ & $0.3141(3)$ & $0.3197(1)$ & $0.2676(1)$ & $105(1)$ \\
$\mathrm{S} 2$ & $-0.0176(2)$ & $0.1278(2)$ & $0.1076(1)$ & $95(1)$ \\
$\mathrm{S} 31$ & $0.0699(9)$ & $0.2712(6)$ & $0.2264(4)$ & $119(4)$ \\
$\mathrm{S} 32$ & $0.0113(7)$ & $0.2325(5)$ & $0.1990(4)$ & $94(3)$ \\
$\mathrm{C} 1$ & $0.2537(6)$ & $0.0504(4)$ & $0.2420(4)$ & $59(2)$ \\
$\mathrm{C} 2$ & $0.3419(9)$ & $0.1116(4)$ & $0.2957(3)$ & $67(2)$ \\
$\mathrm{C} 3$ & $0.4801(7)$ & $0.1347(4)$ & $0.2717(4)$ & $66(2)$ \\
$\mathrm{C} 4$ & $0.4788(6)$ & $0.0831(3)$ & $0.2031(3)$ & $53(2)$ \\
$\mathrm{C} 5$ & $0.3360(6)$ & $0.0356(3)$ & $0.1815(3)$ & $49(2)$ \\
$\mathrm{C} 6$ & $0.1124(8)$ & $-0.0009(5)$ & $0.2540(5)$ & $126(4)$ \\
$\mathrm{C} 7$ & $0.3035(13)$ & $0.1365(6)$ & $0.3739(4)$ & $147(6)$ \\
$\mathrm{C} 8$ & $0.6244(10)$ & $0.1824(5)$ & $0.3202(5)$ & $141(5)$ \\
$\mathrm{C} 9$ & $0.6285(8)$ & $0.0649(5)$ & $0.1759(5)$ & $110(4)$ \\
C10 & $0.2951(9)$ & $-0.0360(4)$ & $0.1187(4)$ & $97(3)$ \\
C11 & $0.1514(7)$ & $0.2867(6)$ & $0.0404(4)$ & $82(3)$ \\
C12 & $0.2202(10)$ & $0.2083(4)$ & $0.0181(3)$ & $74(3)$ \\
C13 & $0.3790(9)$ & $0.2116(4)$ & $0.0483(4)$ & $66(3)$ \\
C14 & $0.4185(8)$ & $0.2857(5)$ & $0.0925(4)$ & $73(3)$ \\
C15 & $0.2815(10)$ & $0.3362(4)$ & $0.0873(4)$ & $74(3)$ \\
C16 & $-0.0138(10)$ & $0.3205(8)$ & $0.0106(6)$ & $211(7)$ \\
C17 & $0.1347(15)$ & $0.1443(7)$ & $-0.0443(4)$ & $226(8)$ \\
C18 & $0.4899(13)$ & $0.1547(7)$ & $0.0138(6)$ & $199(8)$ \\
C19 & $0.5864(10)$ & $0.3204(6)$ & $0.1286(6)$ & $169(6)$ \\
C20 & $0.2663(16)$ & $0.4314(5)$ & $0.1094(5)$ & $231(10)$ \\
& &
\end{tabular}

${ }^{a}$ Equivalent isotropic $U$ defined as one-third of the trace of the orthogonalized $U_{i j}$ tensor.

was solved by using standard Patterson methods, least-squares refinement, and Fourier techniques. All non-hydrogen atoms were refined anisotropically; the hydrogen atoms were included riding on calculated positions (HFIX program of SHELXTL ${ }^{12}$ ). All calculations were performed with the SHELXTL program; ${ }^{12}$ scattering

(12) Sheldrick, G. M. SHELXTL Program, Universităt Göttingen, Göttingen, Germany, 1983 

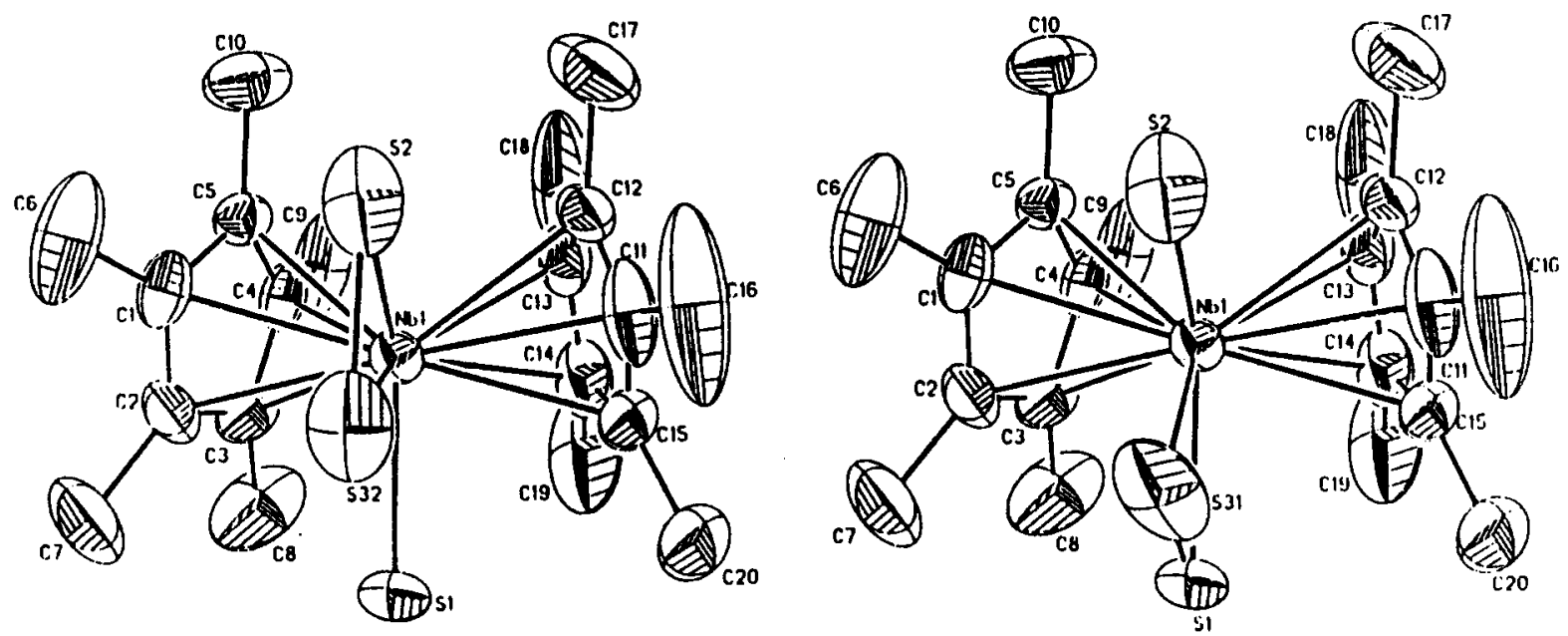

Figure 1. ORTEP plot of 2 (50\% probability level). Two views are given, each of which contains the central $S$ atom in a $50: 50$ statistical distribution. The $\mathrm{H}$ atom bound to S1 or S2 (see text) cannot be localized exactly and is therefore omitted.

factors were taken from ref 13.

$\mathrm{Cp}_{2}^{\prime} \mathrm{TaS}_{2} \mathrm{H}$. A yellow irregularly shaped crystal having the approximate dimensions $0.40 \times 0.16 \times 0.10 \mathrm{~mm}$ was mounted on an Enraf-Nonius CAD4 diffractometer. The unit cell was determined and refined from 25 randomly selected reflections (CAD4 routines). Relevant crystal and data collection parameters are given in Table I. A preliminary search of diffraction maxima and systematic extinctions indicated the unique space group $P 2_{1} / c$. All calculations were carried out by using the Enraf-Nonius SDP library ${ }^{14}$ with neutral-atom scattering factors. Intensities of the 3587 reflections measured were corrected for Lorentz and polarization effects and for linear decay; 2408 unique ones with $I$ $>3 \sigma(l)$ were used in the structure solution and refinement. The structure was solved by conventional Patterson and difference Fourier methods, and no particular difficulty due to decomposition of the crystal was observed. The empirical absorption correction DIFABS $^{16}$ was applied after isotropic refinement of the structure. In the final full-matrix least-squares refinements all non-hydrogen atoms were given anisotropic temperature factors and all hydrogen atoms of $t-\mathrm{BuC}_{5} \mathrm{H}_{4}$ ligands were placed in calculated positions (HYDRO program of SDP), riding on the carbon atoms bearing them, and included with $B_{\text {iso }}$ varying from 5.0 to $13.0 \AA^{2}$. A final difference Fourier map revealed the three strongest peaks at 2.3, 2.2 , and $2.1 \mathrm{e} / \AA^{3}$. The first peak was 2.11 and $1.21 \AA$ away from the $\mathrm{Ta}$ and $\mathrm{S} 2$ atoms, respectively, and located in the $\mathrm{TaS}_{2}$ plane. The attempt to refine it as a hydride was unsuccessful, because its positional parameters varied by more than $2 \AA$ from one cycle to another. Thus, we considered this peak as an artifact due to high electron density in the $\mathrm{TaS}_{2}$ plane. Other difference Fourier peaks are close to the tantalum atom $(0.7-0.9 \AA)$. Final atomic coordinates of non-hydrogen atoms are given in Table III.

\section{Results and Discussion}

Complex 2 was formed from $\left(\mathrm{C}_{5} \mathrm{Me}_{5}\right)_{2} \mathrm{NbBH}_{4}$ and $\mathrm{S}_{8}$ in moderate yields (eq 2). ${ }^{1}$ Two isomeric forms were proposed for 2, of which $2 \mathrm{~A}$ (involving a puckered niobathiacycle and a metal hydride) seemed to be more likely by means of IR and ${ }^{1} \mathrm{H}$ NMR data. ${ }^{1}$ We have now succeeded in obtaining single crystals from toluene, and thus an X-ray diffraction analysis was carried out.

Unfortunately, the result of this study (Table II, Figure 1) has been hampered by a disorder of the central sulfur atom $\mathrm{S} 3$ and the fact that the $\mathrm{H}$ atom could not be

(13) International Tables for X-Ray Crystallography; Kynoch Press: Birmingham, U.K., 1974; Vol. 4.

(14) Frenz, B. A. The Enraf-Nonius CAD4-SDP. A Real Time System for Concurrent X-Ray Data Collection and Crystal Structure Determination. In Computing in Crystallography; Schenk, M., Olthof-Hazekamp, R., Van Koningsveld, M., Eds.; Delft University Press: Delft, Holland, 1978.

(15) Walker, N.; Stuart, D. Acta Crystallogr., Sect. A 1983, A39, 158.
Table III. Atomic Coordinates and Equivalent Isotropic Displacement Parameters $\left(\AA^{2}\right)$ for $\left(t-\mathrm{BuC}_{5} \mathrm{H}_{4}\right)_{2} \mathrm{TaS}_{2} \mathrm{H}(3)$

\begin{tabular}{lllll}
\hline atom & \multicolumn{1}{c}{$x$} & \multicolumn{1}{c}{$y$} & \multicolumn{1}{c}{$z$} & $U_{\text {oq }}{ }^{a}$ \\
\hline $\mathrm{Ta}$ & $0.18050(3)$ & $0.14229(4)$ & $0.69670(3)$ & $34(3)$ \\
$\mathrm{S} 1$ & $0.0999(3)$ & $0.1097(4)$ & $0.8585(2)$ & $75(3)$ \\
$\mathrm{S} 2$ & $0.2445(4)$ & $0.0293(4)$ & $0.8374(3)$ & $94(2)$ \\
$\mathrm{C} 1$ & $0.3028(8)$ & $0.313(1)$ & $0.6671(8)$ & $42(6)$ \\
$\mathrm{C} 2$ & $0.2695(9)$ & $0.330(1)$ & $0.7650(8)$ & $48(7)$ \\
$\mathrm{C} 3$ & $0.1703(9)$ & $0.366(1)$ & $0.7598(8)$ & $52(6)$ \\
$\mathrm{C} 4$ & $0.1420(8)$ & $0.368(1)$ & $0.6604(9)$ & $51(6)$ \\
$\mathrm{C} 5$ & $0.2212(8)$ & $0.335(1)$ & $0.6030(8)$ & $45(6)$ \\
$\mathrm{C} 6$ & $0.4078(9)$ & $0.301(1)$ & $0.635(1)$ & $59(8)$ \\
$\mathrm{C} 7$ & $0.445(1)$ & $0.444(2)$ & $0.624(2)$ & $111(15)$ \\
$\mathrm{C} 8$ & $0.416(1)$ & $0.233(2)$ & $0.535(1)$ & $100(10)$ \\
$\mathrm{C} 9$ & $0.471(1)$ & $0.229(2)$ & $0.711(1)$ & $114(14)$ \\
$\mathrm{C} 11$ & $0.1589(8)$ & $-0.069(1)$ & $0.6035(8)$ & $43(6)$ \\
$\mathrm{C} 12$ & $0.162(1)$ & $0.039(1)$ & $0.5389(8)$ & $56(7)$ \\
$\mathrm{C} 13$ & $0.0814(9)$ & $0.120(1)$ & $0.5494(9)$ & $60(7)$ \\
$\mathrm{C} 14$ & $0.0289(8)$ & $0.067(1)$ & $0.6290(8)$ & $48(6)$ \\
$\mathrm{C} 15$ & $0.0769(8)$ & $-0.048(1)$ & $0.6615(8)$ & $47(6)$ \\
$\mathrm{C} 16$ & $0.219(1)$ & $-0.197(1)$ & $0.600(1)$ & $67(8)$ \\
$\mathrm{C} 17$ & $0.214(1)$ & $-0.274(1)$ & $0.697(1)$ & $112(14)$ \\
$\mathrm{C} 18$ & $0.172(1)$ & $-0.280(2)$ & $0.518(1)$ & $104(15)$ \\
$\mathrm{C} 19$ & $0.324(1)$ & $-0.171(2)$ & $0.582(2)$ & $145(20)$ \\
\end{tabular}

${ }^{a}$ Equivalent isotropic $U$ defined as one-third of the trace of the orthogonalized $\mathbf{U}_{i j}$ tensor.

Table IV. Selected Distances and Angles for 2

\begin{tabular}{lccc} 
& \multicolumn{3}{c}{ Distances $(\AA)$} \\
$\mathrm{Nb}-\mathrm{S} 1$ & $2.511(2)$ & $\mathrm{Nb}-\mathrm{C}(1-5)_{\mathrm{av}}$ & $2.488(6)$ \\
$\mathrm{Nb}-\mathrm{S} 2$ & $2.538(2)$ & $\mathrm{Nb}-\mathrm{C}(11-15)_{\mathrm{av}}$ & $2.493(8)$ \\
$\mathrm{Nb}-\mathrm{S} 31$ & $2.427(9)$ & $\mathrm{S} 1-\mathrm{S} 31$ & $2.167(8)$ \\
$\mathrm{Nb}-\mathrm{S} 32$ & $2.411(7)$ & $\mathrm{S} 2-\mathrm{S} 32$ & $2.178(8)$ \\
\multicolumn{5}{c}{ Angles (deg) } \\
$\mathrm{S} 1-\mathrm{Nb}-\mathrm{S} 2$ & \multicolumn{4}{c}{$123.8(1)$} & $\mathrm{S} 1-\mathrm{Nb}-\mathrm{S} 32$ & $71.7(2)$ \\
$\mathrm{S} 1-\mathrm{Nb}-\mathrm{S} 31$ & $52.0(2)$ & &
\end{tabular}

localized. Nevertheless, the planar $\mathrm{NbS}_{3}$ core of the molecule now found allows a clear attribution of 2 to type $B$, which is characterized by the still rare assembly of a $\mathrm{S}_{2}{ }^{2-}$ and a SH${ }^{-}$ligand at one metal center. The corresponding $\nu_{\mathrm{SH}}$ absorption is obscured in the IR spectrum. ${ }^{16}$ Probably as a consequence of the disorder of the inner $S$ atom the S-S distances (2.17 (1) $\AA$ ) are rather long, ${ }^{17}$ but not too long when compared to S-S ligands in other coordination modes. ${ }^{18}$ The other $\mathrm{Nb}-\mathrm{S}$ and all $\mathrm{Nb}-\mathrm{C}$ bond

(16) It is generally accepted that $\nu_{\mathrm{SH}}$ absorptions are often very weak. See e.g.: Kwon, D.; Real, J.; Curtis, M. D.; Rheingold, A.; Haggarty, B. S. Organometallics 1991, 10, 143.

(17) Müller, A.; Diemann, E. Adv. Inorg. Chem. 1987, 31, 89. 
Table V. Selected Distances and Angles for 3

\begin{tabular}{llll} 
& \multicolumn{3}{c}{ Distances $(\AA)$} \\
$\mathrm{Ta}-\mathrm{S} 1$ & $2.504(4)$ & $\mathrm{Ta}-\mathrm{C}(11-15)_{\mathrm{av}}$ & $2.44(1)$ \\
$\mathrm{Ta}-\mathrm{S} 2$ & $2.388(5)$ & $\mathrm{S} 1-\mathrm{S} 2$ & $2.165(7)$ \\
$\mathrm{Ta}-\mathrm{C}(1-5)_{\mathrm{av}}$ & $2.42(1)$ & & \\
\multicolumn{5}{c}{ Angles $(\mathrm{deg})$} \\
$\mathrm{S} 1-\mathrm{Ta}-\mathrm{S} 2$ & $52.5(2)$ & $\mathrm{M}_{\mathrm{Cp} 1}-\mathrm{Ta}-\mathrm{M}_{\mathrm{Cp} 2}{ }^{a}$ & $131.6(2)$
\end{tabular}

${ }^{a} \mathrm{M}_{\mathrm{Cp} 1}$ and $\mathrm{M}_{\mathrm{C}_{\mathrm{p} 2}}$ are the midpoints of the $\mathrm{Cp}$ rings $\mathrm{C1}-\mathrm{C5}$ and C11-C15, respectively.

lengths (Table IV) do agree well with those already found in polynuclear cyclopentadienylniobium sulfides. ${ }^{1,2}$ Thus, 2 is the first niobocene complex bearing the $\mathrm{NbS}_{2}$ unit which has allowed an exact structure determination. ${ }^{8}$

The reaction of $\mathrm{Cp}_{2}^{\prime} \mathrm{TaH}_{3}$ with excess sulfur gives at ambient temperature the yellow complex 3 as the only product (the liberated gas consists of at least an important portion of $\mathrm{H}_{2} \mathrm{~S}$ ). Reaction times longer than $4 \mathrm{~h}$ and elevated temperatures give rise to the formation of as yet uncharacterized polynuclear compounds. The new com. plex is readily soluble in common organic solvents; its solutions are air-sensitive. For the composition $\mathrm{Cp}_{2}^{\prime} \mathrm{TaS}_{2} \mathrm{H}$, which follows from analytical data, one may imagine the three isomeric forms A-C. As only one resonance for the

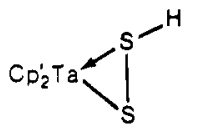

A<smiles>[18O]=S</smiles>

B

3<smiles></smiles>

C tert-butyl substituent is observed in the ${ }^{1} \mathrm{H}$ NMR spectrum, one may rule out isomer $A$, which would require two different environments for the $\mathrm{Cp}$ ligand. In addition, the resonances of the $t$-BuCp protons are close to the values observed in other $\mathrm{Ta}(\mathrm{V})$ complexes reported in this paper, whereas they are rather far from the chemical shifts reported for $\mathrm{Ta}$ (III) complexes such as $\mathrm{Cp}_{2}^{\prime} \mathrm{Ta}(\mathrm{CO}) \mathrm{H} .{ }^{19}$

From spectroscopic data it is not possible to distinguish clearly between isomers B and C. Single crystals of 3 were obtained from toluene/pentane, and an X-ray structure analysis was carried out (Table III). Although an overall weakening of the diffraction pattern was observed during data collection and although the $\mathrm{H}$ atom could not be localized, the structure solution represents a sufficiently broad basis for the discussion of the structure. The core of the molecule is characterized by a $\mathrm{TaS}_{2}$ triangle (Figure 2 , Table V) with an angle of $52.5(2)^{\circ}$ at Ta. This triangle is oriented in such a way that $\mathrm{S} 2$ lies only $0.17 \AA$ outside the plane defined by the gravity centers of both $\mathrm{Cp}$ rings and Ta compared to $-1.85 \AA$ for $S 1$. Such a geometry is only possible for isomer $\mathrm{C}$, whereas in the case of $\mathrm{B}$ a $\pi$-bonding orbital would be localized in the plane bisecting the $\mathrm{Cp}$ rings with the corresponding $\mathrm{S}$ atoms in lateral positions. The formulation of a $\mathrm{S}_{2}$ ligand is also consistent with the presence of a $\nu_{\mathrm{S}-\mathrm{S}}$ absorption at $525 \mathrm{~cm}^{-1}$ in the IR spectrum.

It is striking that, as in 2 , an expansion of the $\mathrm{S}-\mathrm{S}$ bond (2.165 (7) $\AA$ ) is observed. Therefore, one may try to explain this stretching, at least in part, by the strong acceptor properties of the $S_{2}$ ligand. The structural arrangement is further supported by the deshielded ${ }^{1} \mathrm{H}$ NMR resonance signal of the metal hydride at $\delta 2.79$. A similarly low field shift has already been observed for complexes of the type

(18) Brunner, H.; Pfauntsch, J.; Wachter, J.; Nuber, B.; Ziegler, M. L J. Organomet. Chem. 1989, 359, 179.

(19) Reynoud, J. F.; Leblanc, J. C.; Moise, C. Organometallics 1985 4,1059 .

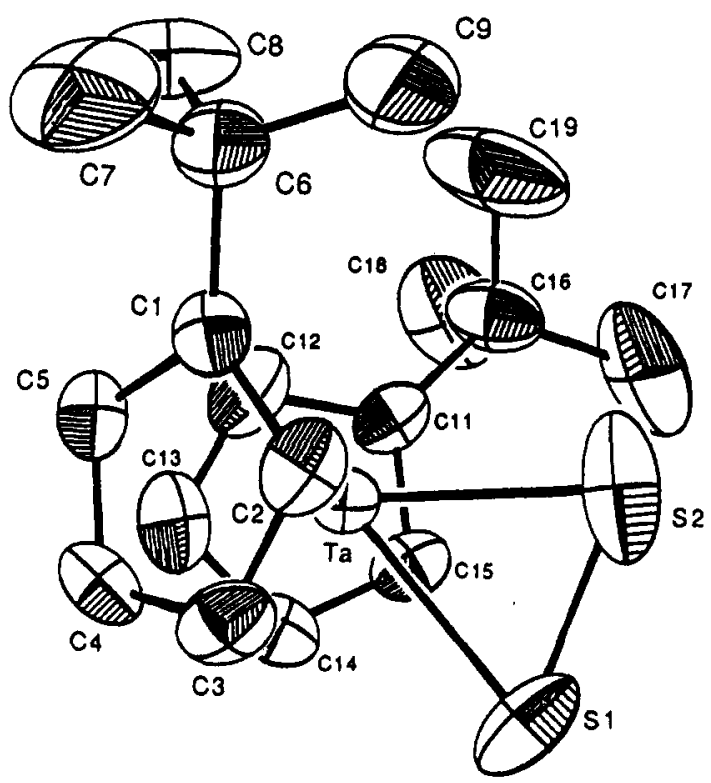

Figure 2. ORTEP plot of 3 (50\% probability level). The $\mathrm{H}$ atom bound to $\mathrm{Ta}$ cannot be localized exactly and is therefore omitted.

$\mathrm{Cp}_{2} \mathrm{Ta}\left(\eta^{2}-\mathrm{L}\right) \mathrm{H}\left(\mathrm{L}=\mathrm{N}_{2} \mathrm{CPh}_{2}, \mathrm{CH}(\mathrm{CN}) \mathrm{NR}\right),{ }^{20}$ which are isosteric with 3. Of speculative character is the assumption of a weak interaction of the metal hydride with the inner $\mathrm{S}$ atom of the $\mathrm{S}_{2}$ ligand in the solid state as a quasi-intermediate between both isomeric forms $\mathrm{A}$ and $\mathrm{C}$. It is not yet clear if such a behavior would explain the presence of two unequal $\mathrm{Te}-\mathrm{S}$ bonds and the missing $\nu_{\mathrm{M}-\mathrm{H}}$ absorption in the IR spectrum.

In contrast to the case for 2 , complex 3 is available in quantities sufficient to allow us to study its chemical reactivity. Preliminary results which are in good agreement with structural type $3 \mathrm{C}$ are summarized in eq 4 . If so-

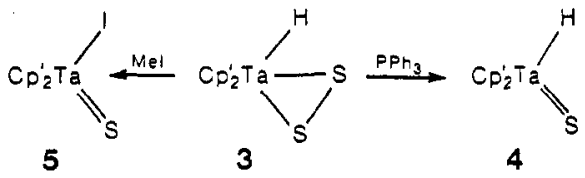

lutions of 3 are treated with equimolar amounts of phosphites or phosphines, one $S$ atom is abstracted to give the pink compound 4. An IR absorption at $1895 \mathrm{~cm}^{-1}$ is indicative of a $\mathrm{Ta}-\mathrm{H}$ moiety, whereas the only strong absorption below $600 \mathrm{~cm}^{-1}$ is tentatively assigned as a $\nu_{T a}-S$ absorption $\left(433 \mathrm{~cm}^{-1}\right)$. The $\nu_{\mathrm{S}-\mathrm{S}}$ absorption of the starting material has disappeared. In the ${ }^{1} \mathrm{H}$ NMR spectrum only small changes are observed for the resonances of the ring protons when compared with those of 3 . The metal hydride resonance of the latter now appears at $\delta+7.10$, a fact which can only be explained by the presence of a $\mathrm{Ta}(\mathrm{V})$ center. ${ }^{21}$ A similar chalcogen abstraction with phosphines has recently been described for the structurally related complex $\mathrm{Cp} *{ }_{2} \mathrm{Ta}\left(\eta^{2}-\mathrm{O}_{2}\right) \mathrm{CH}_{3}{ }^{22}$

In another reaction 3 reacts with $\mathrm{CH}_{3} \mathrm{I}$ to give complex 5 , in which the $\nu_{\mathrm{Ta}-\mathrm{H}}$ and $\nu_{\mathrm{S}-\mathrm{S}}$ absorptions of 3 have disappeared. A new strong absorption at $433 \mathrm{~cm}^{-1}$ is attributed to a $\nu_{\mathrm{T} a=\mathrm{S}}$ frequency. Although the ${ }^{1} \mathrm{H}$ NMR spectrum is of less diagnostic value, it must be stated that all four quadruplets of the ring protons are shifted to lower

(20) Leboeuf, J. F.; Leblanc, J. C.; Moise, C. J. Organomet. Chem. $1989,364, \mathrm{C} 22$

(21) Belmonte, P.; Schrock, R. R.; Churchill, M. R.; Youngs, W. J. J. Am. Chem. Soc. $1980,102,2858$.

(22) von Asselt, A.; Trimmer, M. S.; Henling, L. M.; Bercaw, J. E. J. Am. Chem. Soc. 1988, 110,8254. 
field. As the first step in this reaction we assume that there is likely an attack of $\mathrm{CH}_{3} \mathrm{I}$ at the nucleophilic $\mathrm{S}_{2}$ ligand followed by the elimination of $\mathrm{CH}_{3} \mathrm{SH}$.

All compounds described in this paper exist formally in the oxidation state +5 . The fact that in the related vanadium chalcogen chemistry oxidation state +4 is dominating $\mathrm{g}^{6,7,9,23}$ prompted us to try the synthesis of $\mathrm{Nb}$ (IV) complexes due to eq 1 . However, when $\mathrm{Cp}_{2}^{\prime} \mathrm{NbCl}_{2}$ was reacted with $\mathrm{Li}_{2} \mathrm{~S}_{2}$ or $\mathrm{Li}_{2} \mathrm{~S}_{5}$, the formation of the expected metallathiacycles could not be observed. Although their formation cannot generally be excluded, the reaction took place at such high temperatures (above $100^{\circ} \mathrm{C}$ ) that finally only multinuclear complexes were isolated in a poorly selective reaction in $6 \%(6)$ and $8 \%$ yield (7). The structure of 6 , which is also one of the products of the thermal decomposition of 1 , has already been solved. It is characterized by a set of five different $S_{2}$ ligands and a rather flat $\mathrm{Nb}_{3} \mathrm{O}$ tetrahedron. ${ }^{2}$ The structure of 7 may

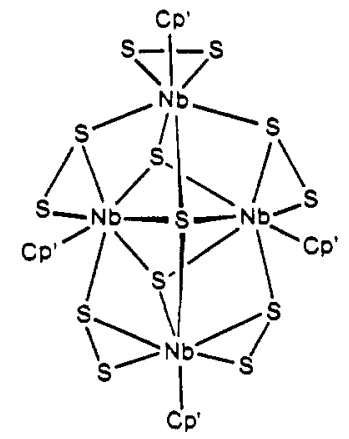

7

be derived from a butterfly-like $\mathrm{Nb}_{4}$ core spanned by a $\mu_{4}-\mathrm{S}$ ligand; a $\mathrm{Ta}$ complex exhibiting such a structure is known. ${ }^{24}$ Then the $\mathrm{Nb}$ centers would be coordinated by mono- and disulfide ligands in such a manner that the molecule contains a symmetry plane. This would be in agreement with the ${ }^{1} \mathrm{H}$ NMR spectrum (three $\mathrm{CH}_{3}$ resonances for the $t$-Bu groups in the ratio $1: 2: 1$ ).

\section{Conclusion}

The starting point for this investigation was the one-step synthesis of the polysulfide complex 1 , which should proceed via distinct intermediates when regarding its rather complex structure. Now, the isolation and characterization of 2 and 3 allows a more detailed insight into

(23) Gambarotta, S.; Floriani, C.; Chiesi-Villa, A.; Guastini, C. J. Chem. Soc., Chem. Commun. 1983, 184.

(24) Fenske, D.; Manê, P. G. Z. Naturforsch. 1989, B44, 531. the reaction of group 5 metallocene hydrides with sulfur, for the variation of the Cp substituents as well as the metal affords a kinetic stabilization of as yet elusive intermediate products. Thus, we propose a general reaction sequence in which the stability of the products depends on the $\pi$ ligands and the metal centers (eq 5). Disulfide complexes,

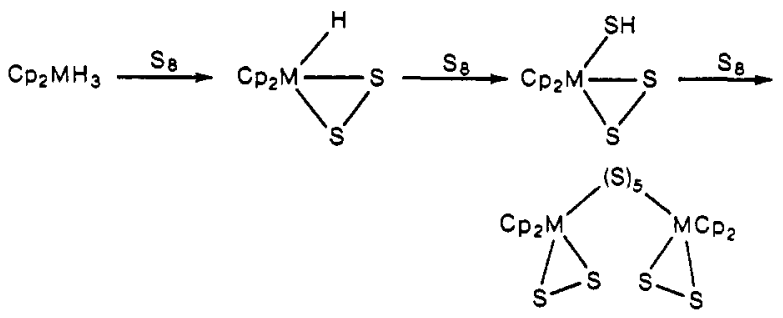

as represented by 3 , still bearing a reactive metal hydride obviously are the first relatively stable intermediates after the attack of the nucleophilic metal center at the $S_{8}$ ring. Then one may imagine the insertion of sulfur into the $\mathrm{M}-\mathrm{H}$ bond, leading in the case of 2 to an isolable product. As the final step oxidative coupling of two SH ligands of two different molecules by sulfur may lead to the bridging pentasulfide ligand being sufficiently stable in $1 .{ }^{25}$ In this context we must cite one of the first observations in niobocene sulfide chemistry: $\mathrm{Cp}_{2} \mathrm{Nb}\left(\mathrm{S}_{2}\right) \mathrm{Cl}$ was found to react with $\mathrm{H}_{2} \mathrm{~S}$ to give a brown product of presumably oligomeric nature of composition $\left(\mathrm{Cp}_{2} \mathrm{NbS}_{4}\right)_{n}{ }^{8 \mathrm{a}}$

All these examples demonstrate that the metallocene sulfide chemistry of $\mathrm{Nb}$ and $\mathrm{Ta}$ is much more complicated than originally assumed. ${ }^{8}$ It also differs considerably from related group 5 chemistry ${ }^{26}$ in that stable metallocene complexes are only formed in the +5 oxidation state and that no dinuclear compounds with a direct metal-metal interaction exist. Further investigations will be addressed to use 3 as a building block in the synthesis of polynuclear complexes and to employ the potential reactivity of its inorganic ligands in organic synthesis.

Registry No. 2, 125303-74-4; 3, 138783-57-0; 4, 138783-58-1; 5, 138783-59-2; 6, 127649-42-7; 7, 127649-43-8; $\left(t-\mathrm{BuC}_{5} \mathrm{H}_{4}\right)_{2} \mathrm{TaH}_{3}$, 84749-48-4; $\mathrm{Cp}_{2}^{\prime} \mathrm{NbCl}_{2}, 61374-53-6 ; \mathrm{Li}_{2} \mathrm{~S}_{5}, 66559-78-2$.

Supplementary Material Available: Tables of bond lengths, bond angles, anisotropic displacement parameters, and $\mathrm{H}$ atom coordinates for 2 and 3 (8 pages); tables of observed and calculated structure factors ( 32 pages). Ordering information is given on any current masthead page.

(25) Further examples of related oxidative couplings of SH ligands are given in: Amarasekera, J.; Rauchfuss, T. B. Inorg. Chem. 1989, 28, 3875.

(26) Draganjac, M.; Rauchfuss, T. B. Angew. Chem., Int. Ed. Engl. 1985, 24, 742. Herberhold, M.; Kuhnlein, M.; Schrepfermann, M.; Ziegler, M. L.; Nuber, B. J. Organomet. Chem. 1990, 398, 259. 